\title{
Towards to an Education for Citizenship: Case of a Learning Experience in a Business School
}

\author{
By Alexandra Jochims Kruel ${ }^{*}$ \\ Elieti Biques Fernandes ${ }^{\dagger}$
}

It was perceived by the authors that their Business undergraduate students have crescent difficulties to understand themselves as part of the society and its needs, as to give attention to social problems as their problems: the students are thinking and acting in a displaced form, far away from their territories and its social dynamics. Thus, the author proposed to work from a social perspective over a semester in three disciplines named Marketing Research, Entrepreneurship and Organizational Experiences. The work involved different activities: reading and critical analysis of academic and everyday texts, images and sounds; creativity exercises; presentations of realistic problem situations, in order to identify causes and consequences, generate decision-making, planning interventions and ways of evaluating actions and results. The activities generated discussions about public safety, environmental sustainability, drug trafficking, social and environmental vulnerability. The authors believe that this work brought more and better reflections about the social reality around the students and give them capabilities to propose, plan and evaluate interventions.

Keywords: education and citizenship, education and management, realistic problem situations

\section{Introduction}

Brazil is a large country, one of the most populous and largest around the world. In the last almost three decades, the country lives again in a democratic situation. Despite this democratic period, the discourse on popular participation in public decisions and the recent economic growth, Brazil has several problems in the political and social field.

In the political field, Brazil has over than 30 political institutions (parties), but most of them without firm identity. This situation obstruct citizens to understand the differences between political parties and their purposes, which generate some reactions: people think that all politicians are the same, that all the parties do the same things and the worst, people do not know that politics is more than the party action and a few common people have interest in understand or participate in a public life, in order to provide solutions to common problems and improve better quality of life.

In the social field, there is a huge social inequality. Even with federal actions on rent-distribution programs, since about 15-20 years ago, many people have been leaving the miserable situation and growing economically,

${ }^{*}$ Professor, Centro University Unilasalle, Brasil.

${ }^{\dagger}$ Professor, Centro University Unilasalle, Brasil. 
but it does not mean that the difference between rich and poor people is being reduced or even ending.

Meanwhile, the entrance in university courses is increasing, and much more students are entering to university life each year. Between the years 1991 and 2000, there was a 95\% expansion in enrollment of students in higher undergraduate level, going up to a total of 2,694,245 students enrolled in undergraduate programs, $33 \%$ of them in public universities and $67 \%$ in private institutions. In this period, there was a decrease in the volume of vacancies in the public sphere and a consequent expansion in the private sector (Soares, 2002). In 2001, was issued the National Plan for Higher Education 2001-2010, aiming at increasing the offer of places in higher education, reduce regional inequalities in vacancies offers and diversify offerings to meet the different needs and demands by region. During the period of the National Plan 20012010 happened a $110.1 \%$ increase in enrollment. At the end of 2010, the Census of Higher Education pointed to a volume of 6,379,299 undergraduate enrollment, $74.2 \%$ of them in the private sphere (Brazilian Ministry of Education, 2011).

This results can be explained by several factors (a) Brazil's economic growth, which has been demanding for more skilled workers; (b) public policies of access and permanence in universities, through increased supply of places in public institutions and increased volume of financial subsidies to students enrolled in private universities; (c) adoption of new formats of courses, as vocational training courses with shorter duration (technological courses) and distance education model (Brazilian Ministry of Education, 2011).

It is important to say that these all students come from different economic and social classes and, clearly, the quality of their previous formation is different. In a way, this is a conquest for the country. On the other hand, it is a challenge for universities, teachers and students to coexist and understand so many different origins and realities which exist among them. In this sense, it was perceived by the authors that their Business undergraduate students also have crescent difficulties to understand themselves as part of the society and its needs, as to give attention to social problems as their problems: the students are thinking and acting in a displaced form, far away from their territories and its social dynamics.

Thus, the authors proposed to work from a social perspective over a semester in three disciplines named Marketing Research, Entrepreneurship and Organizational Experiences, in a Business School of a University Center in Southeast Brazil. The work was based on the pedagogical proposal of Paulo Freire, for who the human being is not only in the world, but with the world. Therefore, education is necessarily relational, that should be linked to the reality of people and should consider the common knowledge in order to generate commitment to the studies and with what generates it.

The work involved different activities: reading and critical analysis of academic and everyday texts, images and sounds, creativity exercises, presentations of realistic problem situations, in order to identify causes and consequences, generate decision-making, planning interventions and ways of 
evaluating actions and results. The activities generated discussions about public safety, environmental sustainability, drug trafficking, social and environmental vulnerability. The work also generated a research to identify the needs of public health system users, suggestions of social and collective enterprises in cases of severe flooding; organization for collecting, storage and distribution of campaign donatives; organization of shelters for homeless by natural disasters and their return home.

The authors believe that this work brought more and better reflections about the social reality around the students and give them capabilities to propose, plan and evaluate interventions. This proposal can enhance students' understanding of their role in society, not just as business and management professionals, but as citizens who have knowledge in business and management and can use this knowledge for the community betterment.

\section{Some Words about Freirian Pedagogic Conception}

This work begun with the freirian educational conception. First of all, it is necessary to talk about the educator Paulo Freire. This notable person built his educational conception from the "Earth condemned" point of view: the people who are excluded, the oppressed people. Freire was a fighter against social injustice, and left a legacy that seeks for a "universal human being ethics", it means: equality, respect and dignity to all, and condemnation to work exploitation. In this sense, he built a frame to an educational practice inseparable to that universal ethics. It means, for him (Freire, 1996), the human being is more than a person who lives in the world. He is a presence in the world, with the world and with the others. He is a presence who thinks and knows about himself, who interferes, transforms, speaks, realizes, compares, evaluates, decides, and breaks. In fact, it is indeed possible to say that people are complex and unfinished being, because while they promote changes in the world, they also change with them.

This conception is believed that its "form is much more to merely train the student in perform tasks and competences" (Freire, 1996, p. 14). So, there is a defense about the teacher's role based on ethics and critics responsibility in the teaching task and educational practice. It is recognized that there is no teaching without students and the relationship between learning and teaching is mutual, is to say, everybody learn and teach: there is no teaching without learning and there is no learning without teaching. In this sense, teaching is not just transferring knowledge, and form is not just shape an accommodated and undecided body, but gives possibilities to students to product and build knowledge.

So, Freire (1996) defends that students must accept themselves as protagonists of knowledge production, not as merely objects that receive information. This conception comprehends that knowledge is built and unfinished; it is a process that can origin a increasing curiosity, which can turn students more creative, critic and, perhaps, more committed. 
In this way, Fischer (as cited in Moraes, 1996) defends that it is not more possible to comprehend the knowledge as a simple combination of information centered in some place (a book, report or even a person) waiting to be transferred to another place (students heads). On the contrary, she defends a dynamic and permanent interaction between protagonist (subject, the student) and object (the information), and the teacher as a mediator, who allows a construction of a rich and effective relation between them. So, according to Fischer (as cited in Moraes, 1996), to the teacher are given the roles of: defy the students to think by themselves; help them in their cognitive and moral developments and autonomy; give them information and help them to produce new information and knowledge; trigger problems and seek for news answers, break paradigms and preconceptions; stimulate an investigative and instigating way of thinking.

Thus, it is necessary run away from the traditional teaching methods in class. The teacher is someone with the role of mediator, provocative and, as Fischer (as cited in Moraes, 1996) could say, sometimes invisible. To Freire (1996), this teacher do initial expositions about some theme and seeks analyze it with the students, in a respectful and affective relation between them, when he provokes the students to built and develop their own critical capabilities and commitment, respecting their own knowledge and learning with them.

\section{Some Words about the Methodological Basis}

From the perspective described above, it was necessary to choose methodological strategies for developing the studies. It was chosen the problematization as basis to educational practices. This is supported in learning from discovery and meaningful learning. The involved learn to learn. In this strategy, students receive the contents in an unfinished description of a problem potentially real, that needs to be reflected and reorganized, as to receive built answers and solutions. So, students must seek for relations, laws and concepts to discover and build the answers. To be meaningful, the contents must be related to previous knowledge and demand to students a favorable attitude and to teachers a mobilizing task (Cyrino \& Toralles-Pereira, 2004).

For Cyrino and Toralles-Pereira (2004), in this meaningful learning, the student is the protagonist and the new learning contents must allow him to defy himself to proceed and advance his knowledge. It means that it is necessary a complex and non linear work of continuities and breakings, in a way that allow to student to overtake his experience and stereotypes, as to provoke new challenges. The learning process is structured not by the accumulated information, but by the net of connections that the student performs.

To develop the work in class was chosen as strategy the problematization methodology. This content will be seen straight away. 


\section{The Problematization Methodology}

The problematization methodology comes from the problematization pedagogy, which is based in the idea that in a world with constant and quick changes, the most important is not the faithful transmission of knowledge and ideas or even the expectancy for an easy and correct behavior of the students, but the increase of students capabilities in detect real problems and seek for creative solutions. So, the students are taken as agents for social transformation, and the capabilities to be developed are: do the relevant questions in any situations, to understand them and be able to solve them in a proper way (Bordenave, 1983).

Thus, the problematization methodology involves an identification of reality problems, on students' side. They identify problems by observing reality, from study questions pointed by the teacher. After this identification, it takes place the problematization of reality situation. This methodology generally is developed in five steps (Berbel, 1998; Bordenave, 1983):

1. Social reality observation from a theme or content for study: teacher guides students to observe and make notes about this theme or content, and can help them, using general questions. In this step, students can identify difficulties, differences, absences, as to situations that need interventions. It is a stage to identify and describe a problematic situation.

2. Key-points identification: it means that students must reflect about important aspects of the problematic situation observed, and they can perceive that problems are often complex and multicausal. In this stage, students identify which key-points must be theoretical studied to understand the problem.

3. Theorization: in this stage, happens the theoretical study, and students must seek for technical information, they do researches about the identified key-points. They can do interviews, read books and journals (academic and/or commercial), go to conferences, visit places, and other important movements to find answers for their questions. In this stage, they also analyze the collected information, and produce theorization about the causes and consequences of the problematic situation.

4. Production of solution hypothesis from the collected and analyzed information: in this stage, students use the information to build solution purposes to the problem situation. They need to answer: what is necessary to do to solve this problem? What actions and resources are needed? How the actions, use of resources and results can be evaluated?

5. Practice (application in reality): it means overtake the intellectual work and assume a commitment with the problem situation and its possibilities of solution. It is a social and political commitment. The student can learn to generalize the knowledge to different situations and identify when the answers obtained cannot be used. 
It is important to remind that in this methodology, there is a demand about the teacher and students posture: to both are given the responsibility of being reflexive and critic. Besides, after the study of a problem, others can appear, as results of the deep study of the first problem (Berbel, 1998).

\section{The Activities in Class and Results}

This work was developed over a semester in three disciplines named Marketing Research, Entrepreneurship and Organizational Experiences, in the Business School of the University Center in Southeast Brazil. In these three disciplines participated about 130 students.

It is important to remind that a Business School forms people who will work mostly as leaders, managers, executives, CEOs, entrepreneurs. It means, professionals that everyday take decisions and define ways to organizations and, in consequence, too many people. Business is an area for professional formation mostly for management, and is considered for many as "guardian of capitalism". However, there are many kinds of organizations, not just big corporations. It is possible recognize that an organization can be a structural company or a movement, like a worker parade.

This is the first breaking of this work: do not understand and study just business companies, but different organizations. In other words: one company can be an organization, but not all organizations are companies. Thus, the first task in all courses was to overtake the understanding about management exclusive for companies and reflects about the concept of organization as structure and movement. This task involved business and management lectures and debates, and the use of images.

The work involved different activities, seeking to problematize real situations, three of them described above.

\section{Marketing Research Course and the Life in Favelas' (slums)}

This activity was developed in Marketing Research course, which aimed to provide the necessary knowledge and competences to students to perform researche in the marketing field. To American Marketing Association and European Society for Opinion and Marketing Research (Mattar, 2006), Marketing Research can be defined as a function linking consumer, client and general public to Marketing through information, which is used to identify and define opportunities and problems, generate and evaluate actions, monitor performance. It specifies the necessary information, designs the method for collecting and analyzing data and communicates results and its implications.

It started with the projection of a big picture of a Brazilian favela, intentionally upside down. The students were not warned about the picture position. At the first task each student had to say one word that they could think about that image. Many words were spoken and written, most of them very negative. This technique is one form to identify social representations. 
Note that a favela is often described by their conditions of overcrowding, poor or informal housing, inadequate access to sanitation, clear water and insecurity of tenure of housing. But, not all urban poor people live in favelas, and not all people who live in favelas are poor. In any case, in Brazil, near 36\% of the urban population lives in favelas (51.7 million people). It is the third country in the world in this conditions (China comes first, with 193.8 million people and India, in second, with 158.4 million people), according to Davis (2006).

Since this, we started a debate about the image and the words said by students, with some questions: what is it? What it means? Which feelings it brings? Almost all of the students spoke bad sensations and information about the slum's life and few spoke about opportunities to create small business and improve the quality of life, and also perform researches. The debate could bring themes as: living in small spaces and privacy, drugs traffic, differences between cultures, social differences, social and environmental vulnerability and sustainability, among others... . As a common line, the debates had the public interest and the life in community.

It is important to say that a background in social, economical, political and historical basis is always necessary in this kind of work. If not, it is too risky and can generate empty reflections. Thus, it was studied about the growing of urban giant cities (megalopolises) around the world, and their impacts, as crescent inequalities, mostly in economical field. It means: few or none planning cities in order to support the volume of persons and their needs for space, food and public services; reduction of rural areas, which impacts on food production and quality; sending people with lower income to less secure areas for living; among other possibilities (Davis, 2006).

The last debate of this stage was developed after putting the image of the slum in the right side: this was a form to provoke the students to the fact that we can not always see everything as they really are, because they are so complex.

After this experience, all students were demanded to project and perform marketing researches. Some of the students made researches about themes that were related to the debates about public interest and life in community.

- Public safety and the citizen preference to live in closed neighborhoods, to prevent being victims of criminality.

- Needs and wishes from citizen to improve and qualify the public health system in the city.

- Citizen knowledge and preference about sustainable electronic devices, as a way to protect environment.

It is important to say that these researches generate a search by understand the themes, and the presentation of results generate more debates about the original themes and the results. It is possible that this work can be part of new activities, including in other courses, and is not necessarily a finished task. It is also important to note that this activity can promote long-terms results, in order 
to make students more observers and questioning of the social reality. Moreover, these students are the future management professionals, so, with this educational freirian proposal, they can be better prepared and committed to the development of targeted projects and policies to improve people's lives.

\section{Organizational Experiences Course and the Severe Flooding}

This activity was developed in Organizational Experiences course, which objective was approximate theoretical studies to real life in organizations.

During the course, in three months, took place three events of severe rain and flooding in the city. Thus, many students could not come to class because the streets were impassable or flooded or even worst, the students were homeless. These repeated situations were the base for a deep study.

The activity started with the reconnaissance that many colleagues were not in class during these events because of the rain and its huge effect, such as the flooding. This moment was important because made the students perceive that the problem is near to everyone. Then, it was made a brief explanation about the urban flooding as phenomena, which is increasing each year, all around the world. The students were invited to think about the flooding in term of causes, consequences, decision-making in organizations in this situation and purposes to solve or reduce the problem. After this, the students read a text about the theme, explaining about the cost of lives and the economic costs of flooding.

The activity generated discussions about environmental sustainability, social and environmental vulnerability, government and society duties, solidarity and humanitarian logistics. The work also generated some action plans in order to:

- install and organize temporary shelters for homeless by natural disasters;

- organize a donation campaign of clothes, water, food, shoes, stoves and refrigerators, personal care products, blankets, linen, mattresses;

- organize the logistical process (collecting, storage and distribution of campaign donations) in the temporary shelters;

- organize the return home process (house repairs and cleanings, and people transport from temporary shelters to their homes).

It is important to say that this activity used many concepts from management studies on logistics, and that this work generates a new vision to students about the flooding and its impacts over communities and people lives.

\section{Entrepreneurship Course and Collective Plans to help with Peoples' Problems}

This activity was developed in Entrepreneurship Course, which objective is to provide knowledge to students in order to be able to perform and evaluate business plans. A business plan is a document which presents the basic ideas of 
the entrepreneur, describes information about the current context, the need to open the business and the managing plans, in terms of resources, processes and outcome expectations.

During the course, all students designed business plans in small groups. Each class built parts of their business plans: human resources, marketing, operations, financial... . They created pubs, bakery, restaurants, gym and shops, all with the goal of profit. Note that the business centralities were chosen in the beginning of the task.

Simultaneously, they were presented to other questions about entrepreneurship, other forms that entrepreneurship can assume, beyond business, as: environmental, social, collective, feminine, entrepreneurship. They read texts and analyzed real images, as parades, organic market-places, workers strikes, schools gardens, flooding, and events as the Confederation Cup and the Pope's visit to Brazil. This material and those themes were debated, in order to comprehend society as context for entrepreneurship in different needs and possibilities.

After ending the business plans, was demanded to the groups of this Course to think about the social needs in the city, and with each other groups identify possibilities to develop collective entrepreneurships. In this task, were planned the following activities:

- visits, parties and gifts to poor elderly people who live apart from their families to children and teenagers who live in orphanage;

- different courses and workshops to women and teenagers, to learn about services and how to produce things, in order to obtain profits (cooking, handicraft, seam, gardening, repairs);

- donation of products from their business, mostly food;

- creation of one special day, when poor people could have documents emitted, have the hair cut, guidance in health care and educations, vaccines, blood donation... .

It is important to say that this last result was possible just after demand to the students, even after so many theoretical debates.

\section{Conclusions}

Reminding Paulo Freire, as more the teacher make possible to students perceive themselves as being in the world, more they will feel defied to answer the new challenge. This belief challenged the authors to make this work.

According to Bordenave (1983), this way of education can generate important results in individual and in social context: students are more motivated and active in class, doing questions and expressing opinions; meaningful learning process; developing intellectual capabilities in observation, analyses, evaluation, understanding and overtaking; more cooperation between students and workgroups; over passing and reducing 
conflicts as part of learning process; same status of teacher and students; more cooperation for seek solutions to common problems, among others.

However, as points Berbel (1998), in this methodological posture, there is no total control about results in terms of knowledge. It is not possible to predict all results, and can be found many surprises, because of the dynamic and complex reality studied. The most important is the experience lived by the teacher, the students and the possibility of increasing commitment and not to predict knowledge.

Furthermore, it is important to note that Freirian approach is not by consensus in the Brazilian educational practice and this happens for various reasons. One of them, perhaps the most important, is because this way of thinking and education practice is very "dislodging". It shakes political, ontological, philosophical bases. It demands a different posture from educators, institutions, and even from governments, because this educational approach seeks for a deep social change: from the transmission of the knowledge to the construction of a conscious, dialogical, critical and liberating education. This means sharing the knowledge, responsibilities and power. It means that is is important to recognize that students and educators have the same value with different acquirements. It means that is necessary to empower the students (first of all, citizens), so that the society can be turned deeply empowered and can truly seek for its needs and wishes, even against the institutional, economical and political structures. Thus, this can be considered as a kind of micro revolution and, as all small movements, it takes long-terms and can be misunderstood by someone, and adopted by other. So, it is not possible to be naively and ensure that this proposal will be consensed or can be widely institutionalized, even in democratic countries, because it goes against power structures historically, politically and economically imposed, all around the world.

At least, we believe that this work brought more and better reflections about the social reality to the students and give them capabilities to propose, plan and evaluate interventions. This proposal can enhance students' understanding of their role in society, not just as business and management professionals, but as citizens who have knowledge in business and management and can use this knowledge for the community betterment.

This is not an easy job, with quick results. It is complex and requires patience, perseverance, but we think that it worth.

\section{Acknowledgment}

Our thanks to our students, to University Center UNILASALLE and our families. 


\section{References}

Berbel, N. A. N. (1998). "Problematization" and problem-based Learning: different words or different ways? Interface-Comunicação, Saúde, Educação, 2(2), 139154.

Bordenave, J. E. D. (1983). Alguns fatores pedagógicos [Some pedagogical factors]. CadRHU, 261-268. Retrieved from http://bit.ly/1aRf38t.

Brasilian Ministry of Education (2011). Censo da Educação Superior 2010 [Census of Higher Education 2010]. Brazil: (1-24). Retrieved from http://bit.ly/1Qi6apg.

Cyrino, E. G. \& Toralles-Pereira, M. L. (2004). Discovery-based teaching and learning strategies in health: problematization and problem-based learning. Cadernos de Saúde Pública, 20(3), 780-788.

Davis, M. (2006). Planet of Slums. São Paulo, Brazil: Boitempo.

Freire, P. (1996). Pedagogia da Autonomia: Saberes Necessários à Prática Educativa [Pedagogy of Autonomy: Necessary Knowledge for Educational Practice]. São Paulo, Brazil: Paz e Terra.

Mattar, F. N. (2006). Marketing Reasearch: Methodology and Planning. São Paulo, Brazil: Atlas.

Moraes, V. (1996). Prática docente na universidade: uma questão menor? [Teaching practice at university: a minor issue?]. In: Melhoria do Ensino e Capacitação Docente. Porto Alegre, Brazil: Editora da Universidade (p. 46-53).

Soares, M. S. A. (2002). Os principais atores da educação superior no Brasil [The main actors of higher education in Brazil]. In: A Educação Superior no Brasil. Porto Alegre, Brazil: Instituto Nacional para a Educação Superior na América Latina e no Caribe/IESALC-UNESCO (p. 155-184). 
